\title{
Sugar beet (Beta vulgaris L.) storage quality in large outdoor piles is impacted by pile management but not by nitrogen fertilizer or cultivar
}

\author{
Laura L. Van Eerd ${ }^{1,2}$, Katelyn A. Congreves ${ }^{1,2}$, and John W. Zandstra ${ }^{2}$ \\ ${ }^{1}$ School of Environmental Sciences; and ${ }^{2}$ University of Guelph Ridgetown Campus, Ridgetown, Ontario, Canada \\ NOP 2 CO (e-mail: Ivaneerd@ridgetownc.uoguelph.ca). Received 23 March 2011, accepted 5 August 2011.
}

\begin{abstract}
Van Eerd, L. L., Congreves, K. A. and Zandstra, J. W. 2012. Sugar beet (Beta vulgaris L.) storage quality in large outdoor piles is impacted by pile management but not by nitrogen fertilizer or cultivar. Can. J. Plant Sci. 92: Xxx-Xxx. Even though storage results in lower sucrose recovery from sugar beets, physical constraints dictate that a significant proportion of the sugar beet crop can be stored up to $120 \mathrm{~d}$ before processing. From 2006 to 2010 , N fertilization $\left(0-220 \mathrm{~kg} \mathrm{~N}^{-1}\right)$, sugar beet cultivar, and pile management method were independently evaluated to determine their effects on sugar beet storability in large outdoor piles. At harvest, five representative sugar beet samples from the $\mathrm{N}$ and cultivar field trials were placed in a large outdoor storage pile. Sugar beet quality assessments were taken at harvest and three times over the storage season. On the last retrieval date only, sugar beet samples were retrieved from piles managed via the length- vs. end-removal method. Although there were differences among $\mathrm{N}$ treatments and cultivars in sugar beet quality at harvest, there were no storage date by $\mathrm{N}$ treatment or storage date by cultivar interactions for any parameters measured indicating that $\mathrm{N}$ fertilization or cultivar did not influence the ability to maintain sugar beet quality in large outdoor piles. The lengthremoval method of pile management had better quality sugar beets compared with the standard end-removal method. Hence, sugar beet producers do not need to modify production practices to optimize storability, but sugar beet processors can improve sucrose recovery by removing sugar beets lengthwise along both sides of large piles as opposed to the standard end-removal method.
\end{abstract}

Key words: Sucrose, pile removal, ammonium nitrogen fertilizer, variety, EuroMaus

Van Eerd, L. L., Congreves, K. A. et Zandstra, J. W. 2012. La qualité de la betterave sucrière (Beta vulgaris L.) durant le stockage extérieur en tas importants est affectée par la méthode de gestion des stocks, mais pas par l'usage d'engrais azotés ni le cultivar. Can. J. Plant Sci. 92: xxx-xxx. Bien que le stockage réduise la quantité de sucrose extraite de la betterave sucrière, les contraintes physiques nécessite l'entreposage d'une part importante de la récolte avant transformation pendant un maximum de 120 jours. De 2006 à 2010, les auteurs ont évalué séparément la fertilisation avec des engrais azotés ( 0 à $220 \mathrm{~kg}$ de $\mathrm{N}$ par hectare), le cultivar et la méthode de gestion des stocks en vue d'établir l'incidence de ces paramètres sur la capacité d'entreposage des betteraves sucrières en gros tas extérieurs. À la récolte, ils ont prélevé cinq échantillons représentatifs de betteraves dans les parcelles soumises aux essais de fertilisation $\mathrm{N}$ et de cultivar, et les ont déposés dans des amas importants stockés à l'extérieur. Ils ont ensuite évalué la qualité des betteraves à la récolte et à trois autres moments, durant l'entreposage. À la dernière date seulement, ils ont récupéré les échantillons des tas gérés selon la durée d'entreposage ou par récupération à une extrémité de l'amas. Bien que l'usage d'engrais $\mathrm{N}$ et le cultivar entraînent des variations au niveau de la qualité à la récolte, il n'existe aucune interaction entre la fertilisation $\mathrm{N}$ ou la date de stockage et le cultivar, quel que soit le paramètre mesuré, signe que les engrais $\mathrm{N}$ et le cultivar n'exercent aucune influence sur la capacité de la betterave à conserver sa qualité quand elle est stockée en tas importants, à l'extérieur. La gestion des stocks par récupération en fonction de la durée d'entreposage donne des betteraves de meilleure qualité que la méthode usuelle, qui consiste à prélever l'extrémité de la pile. Par conséquent, les producteurs de betterave sucrière n'ont pas besoin de modifier leurs pratiques culturales pour optimiser les capacités de stockage de leur produit. En revanche, les transformateurs pourraient accroître la quantité de sucrose extraite en prélevant les betteraves selon leur durée d'entreposage, des deux côtés de la pile, au lieu de ne les prélever qu'à une extrémité.

Mots clés: Sucrose, extraction des stocks, engrais azoté ammonium, variété, EuroMaus

In 2007, Canadian sugar beet production had a farmgate value of $\$ 9.1$ million and $\$ 39$ million for about 95 and 600 growers on approximately 4000 and 13800 ha in Ontario (Ontario Sugarbeet Growers Association, 2008, unpublished data) and Alberta (Chaudhary 2009), respectively. Sugar beets grown in North America are produced under grower-owned cooperatives that process sugar beets into sucrose. As opposed to paying growers based on tonnage only, as of 2007, Michigan Sugar Company Inc. (MSC) paid growers based on sucrose content and sugar beet tonnage. Thus, methods that maximize sucrose production and minimize sucrose losses would be beneficial for all producers, who share

Abbreviations: CJP, clear juice purity; MSC, Michigan Sugar Company Inc.; RWS, recoverable white sugar 
cooperative profits. Considering the potential for significant sucrose losses during storage, research should focus on minimizing losses during this period.

The physical constraints of sugar beet processing operations dictate that much of the crop be stored for a portion of the winter (up to $120 \mathrm{~d}$ ), even though the practice results in a decline in sucrose recovery. During storage, sugar beets undergo chemical alterations and the amount of recoverable white sucrose tends to decline over time. Other than sucrose loss due to root respiration, sugar beet sucrose losses during storage can be attributed to sugar beet physical injury (Cole 1977; Wyse and Peterson 1979), raffinose synthesis, sugar inversion, and fluctuations in storage temperature (Cole and Bugbee 1976). Sucrose losses during storage can be substantial, and are estimated at 250-500 g sucrose $\mathrm{Mg}^{-1} \mathrm{~d}^{-1}$ (Bugbee 1993). Not only do storage conditions influence sugar beet storability, but Martin et al. (2001a) observed that pre-harvest and harvest factors may affect sugar beet quality, which, in turn, may affect storage and processing quality.

Observations at sugar beet storage piles have also raised the question of whether or not different sugar beet production practices have an effect on sugar beet storability. The winters of 2004-2005 and 2005-2006 were unusually warm in southwestern Ontario, which likely contributed to significant rotting in sugar beet storage piles. During the 2004-2005 storage period, an estimated $40000 \mathrm{Mg}$ of sugar beets were discarded in Ontario, which is equivalent to a loss of $24 \%$ of the stored Ontario crop and similar losses were observed at each of MSC's 14 other piling stations (Wayne Martin, MSC, personal communication). While warm conditions resulted in challenging storage conditions, other factors also seemed to be involved. As the rotting sugar beets were removed from storage, MSC personnel noted that side-by-side layers in the pile, suggesting sugar beets from different loads/producers, varied in quality with some layers being of acceptable quality for processing while others were rotted (Wayne Martin, MSC, personal communication). Hence, the observations indicated that different production practices may have had an influence on sugar beet storability, especially under poor storage conditions. However, it is not known which production practices affected sucrose loss and rotting during storage. Although weather and sugar beet handling at harvest are known to impact storage losses (Cole 1977; Scott and Jaggard 2000), there is little information on the impact of grower practices such as fertility and/or crop cultivar on storage losses.

One critical pre-harvest factor that influences sugar beet quality is $\mathrm{N}$ fertility, which is negatively correlated to sucrose concentration and quality (Eslami et al. 1988; Bilbao et al. 2004). Thus, the application of an appropriate level of $\mathrm{N}$ fertilization is crucial to optimize sucrose production. Although the impact of $\mathrm{N}$ fertilizer rate on sugar beet yield, recoverable white sucrose and purity at harvest is well understood (Eslami et al. 1988;
Bilbao et al. 2004), very little is known about the impact of $\mathrm{N}$ fertility on sucrose losses or susceptibility to rotting during long-term storage in large piles.

Sugar beet cultivar may be another pre-harvest factor that affects sugar beet storability, particularly because varieties differ significantly in sucrose content. Small differences in $\mathrm{N}$ response among varieties have been observed (Stevens et al. 2008), which may contribute to differences among varieties in storage characteristics. There are inconsistent results in the literature regarding cultivar influence on storability, as some studies have found evidence of varietal differences in storability (Akeson and Widner 1981; Martin et al. 2001b; Kenter and Hoffmann 2009), while others have not (Campbell and Klotz 2007). Therefore, sugar beet cultivar may be a contributing factor to sugar beet storage losses and should be further evaluated.

Beyond production practices, storage losses may be minimized by modifying sugar beet pile management. Reducing damage to sugar beets or any other storage roots, such as carrots and turnip, increases storability and minimizes rots. For instance, mechanical damage increases sugar beet respiration and significantly lowers sucrose content over the storage period (Cole 1977). However, there may be an opportunity to optimize the method of removing sugar beets from storage to minimize storage losses. In long-term storage piles, an outer $1 \mathrm{~m}$ layer of deteriorated sugar beets forms in response to dehydration and freeze-thaw cycles. Akeson et al. (1974) found that this outer rind contributes to considerable recoverable sugar loss. In the standard pile removal method, sugar beets are removed at shipping from the face-end of the pile with large loaders. An alternative is to remove sugar beets down the length of the pile on each side using a EuroMaus ${ }^{\circledR}$. With the length-removal method, the rind does not form along the length of the pile and may provide better overall pile ventilation. Considering that the length-removal method removes a larger area of the outer pile compared with the standard end-removal method, sucrose losses may be minimized by employing the new length-removal method.

Developing methods to improve storage quality will ultimately increase sucrose recovery in the processing plant and thus profitability for the grower-owned cooperative. Therefore, the objectives of this research were to evaluate the influence of $\mathrm{N}$ fertilization, sugar beet cultivar and pile management practices on sucrose losses during storage in large outdoor piles.

\section{MATERIALS AND METHODS}

A study over three storage seasons was conducted to determine the independent effect of $\mathrm{N}$ fertilization and cultivar on sugar beet storage losses in commercial production fields and at MSC's Dover Piling Station near Chatham in southwestern Ontario. Field studies were conducted on a Brookston clay loam to silty clay loam soil with 3.3 to $4.4 \%$ organic matter and $\mathrm{pH}$ of 
Table 1. Selected soil characteristics of sugar beet nitrogen fertilizer experimental sites in Dover, Ontario, Canada, during 2006-2008

\begin{tabular}{|c|c|c|c|}
\hline Characteristic $^{\mathbf{z}}$ & 2006 & 2007 & 2008 \\
\hline $\mathrm{pH}$ & 7.4 & 6.8 & 7.4 \\
\hline Soil texture & Clay loam & Clay loam & Silty clay loam \\
\hline sand:silt:clay (\%) & $33: 30: 37$ & $24: 45: 31$ & 7:57:36 \\
\hline OM $(\%)$ & 4.4 & 3.9 & 3.3 \\
\hline $\begin{array}{l}\text { Cation exchange capacity } \\
\text { (MEQ } 100 \mathrm{~g}^{-1} \text { ) }\end{array}$ & 38.9 & 28 & 27.3 \\
\hline \multicolumn{4}{|l|}{ Preplant nutrients ( $\mathrm{mg} \mathrm{kg}^{-1}$ ) } \\
\hline Nitrate-N & 11 & 9 & 12 \\
\hline Phosphorus & 24 & 29 & 20 \\
\hline Potassium & 171 & 241 & 148 \\
\hline Calcium & 6184 & 4416 & 5944 \\
\hline Magnesium & 765 & 495 & 406 \\
\hline
\end{tabular}

${ }^{\mathrm{z}}$ Soil sample depth was $15 \mathrm{~cm}$ for all parameters except nitrate-N,

6.8 to 7.4 (Table 1). Sites were in different fields each year but were under the same production practices, with field corn (Zea mays L.) as the previous crop. All nutrients, other than $\mathrm{N}$ fertilization, were based on soil testing and typical Ontario production practices. Typical pest control and other field operations were followed. Air and soil temperature and precipitation data were collected (Table 2). Sugar beets were seeded on 28, 19, and 23 April 2006, 2007, and 2008, and 8 May 2009 , respectively at 128500 seeds ha ${ }^{-1}$ with $76 \mathrm{~cm}$ between plant rows and seeds planted $10 \mathrm{~cm}$ apart. At approximately $4 \mathrm{wk}$ after seeding, stand counts from $2 \mathrm{~m}$ of the middle two rows were taken.

\section{Nitrogen Trial}

A randomized complete block design with four replications was used for the $\mathrm{N}$ trial with cultivars Crystal 271, 963 and 827RR in 2006, 2007, and 2008, respectively. Plots were $8 \mathrm{~m}$ by $4.6 \mathrm{~m}$ or 6 rows wide. Ammonium nitrate was applied in 2006 and 2007 but due to its limited availability, calcium ammonium nitrate was applied in 2008. Nitrogen fertilizer was hand broadcast at planting at $0,56,112,168$ and $225 \mathrm{~kg} \mathrm{~N}^{-1}$. The influence of timing of $\mathrm{N}$ fertilizer application was evaluated with split applications of $56+56$ and $84+$ $84 \mathrm{~kg} \mathrm{~N} \mathrm{ha}^{-1}$. Ammonium nitrate was broadcasted by hand with the first application preplant and the second application on 6, 11 and 12 June 2006, 2007, and 2008, respectively. At harvest, after collection of leaf and crown tissue from six sugar beet plants, a commercial mechanical topper removed sugar beet tops from the entire $\mathrm{N}$ trial area. Approximately $6 \mathrm{~m}$ of the center two rows were machine harvested with a single row harvester. Fresh weights were used to calculate marketable yield.

For total $\mathrm{N}$ analysis at harvest, foliage and roots from five sugar beets were weighed, sliced, and dried at $60^{\circ} \mathrm{C}$. After determining dry weights, a representative sample of dried plant tissue was ground in a Wiley mill with a $2 \mathrm{~mm}$ diameter opening mesh screen. Total $\mathrm{N}$ content

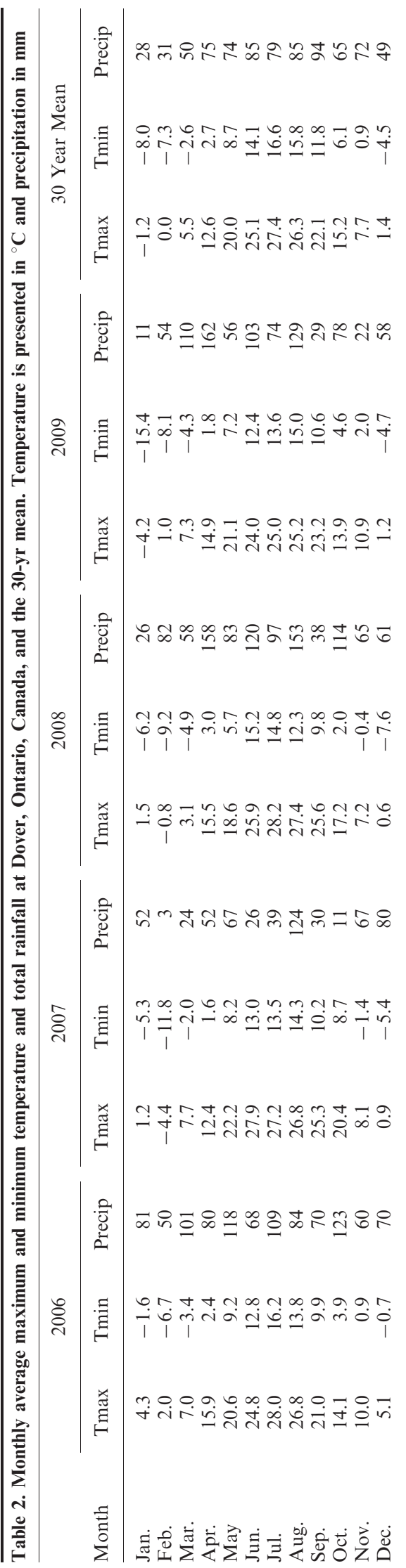


in plant biomass was determined by dry combustion method (Rutherford et al. 2008) using a LECO CN determinator (Leco Corporation, St. Joseph, MI) at an Ontario certified laboratory (A\&L Canada Laboratories Inc., London, $\mathrm{ON}$ ). Percent total $\mathrm{N}$ content was converted to $\mathrm{kg} \mathrm{N}^{-1}$ based on root and shoot dry weights.

\section{Variety Trial}

Sugar beets harvested from an industry-supported Sugar Beet Advancement Variety Trial in 2007-2009 (Michigan State University 2007-2009) were used to assess storage losses in large outdoor piles. Twelve, four, and ten varieties were planted in 2007, 2008, and 2009, respectively, and reflect the industry transition to Roundup Ready ${ }^{\circledR}$ varieties. Roundup Ready ${ }^{\circledR}$ varieties were planted in 0,60 and $>98 \%$ of the Ontario and Michigan sugar beet acreage in 2007, 2008, and 2009, respectively. The cultivar trial was a randomized strip trial with three or four replications. Strips were $4.6 \mathrm{~m}$ (6 rows) wide by the length of the field, at least $330 \mathrm{~m}$. After mechanical harvest and transport to the piling yard, random samples were collected as the sugar beets passed over the pilers, in order to simulate normal handling conditions.

\section{Sugar Beet Storage and Quality}

For $\mathrm{N}$ and cultivar trials, sugar beets from each plot were randomly partitioned into five nylon mesh bags
To compare the effect of pile removal management on storage quality, one container was placed in a different pile, which was managed with the standard end-removal method and retrieved on the final day of storage each season. With the end-removal method, sugar beets were taken from the face end $(60 \times 5.5 \mathrm{~m})$ of the pile and loaded into trailers for transportation to the sugar refinery. With the new length-removal method, approximately $1.5 \mathrm{~m}$ of sugar beets was raked from along the length of the pile $(305 \mathrm{~m})$ onto the ground and elevated, cleaned, and loaded into trailers with a modified EuroMaus ${ }^{\circledR}$ (ROPA-Fahrzeug und Maschinenbau $\mathrm{GmbH}$. Herrngiersdorf, Germany). Sugar beet removal was from both sides of the pile for the length-removal method. Both piles were not covered norventilated.

At harvest and each retrieval date, sampled sugar beets were washed, weighed, and cut with a rasping circular saw to obtain $1 \mathrm{~L}$ of brei (macerated root material). Brei was frozen and shipped to MSC for analyses of sucrose and quality parameters according to industry standards (Carruthers and Oldfield 1961). Sucrose content was determined by the polarimeter method (Halvorson et al. 1978), and clear juice purity (CJP), as well as brei impurity amino- $\mathrm{N}$ were determined according to methods described by Last et al. (1976).

Recovery of sucrose in the processing factory was estimated as recoverable white sucrose (RWS) per fresh weight ton of sugar beets, and calculated as:

$\mathrm{RWS}=((\%$ sucrose $\times 18.4)-22) \times((1-(60 /(\% \mathrm{CJP}-3.5))) / 0.4)($ Wayne Martin, MSC, personal communication $)$.

with approximately 10 roots per bag. One sample was analyzed for sucrose content and quality parameters at harvest. Weights and root number were recorded and the remaining four samples were placed into one of four well-ventilated steel mesh containers. The $0.75 \mathrm{~m}^{3}$ volume containers consisted of $5-\mathrm{mm}$ diameter rods spaced $5 \mathrm{~cm}$ apart. Once all samples were placed in the appropriate containers, the cages were filled with loose sugar beets and placed on top of approximately $0.6 \mathrm{~m}$ of sugar beets in the middle of a large pile at MSC's Dover Piling Station (Chatham-Kent, ON). The containers were buried with sugar beets by the pilers within $5 \mathrm{~h}$. The outdoor sugar beet pile was $305 \mathrm{~m}$ long by $60 \mathrm{~m}$ wide by $5.5 \mathrm{~m}$ high. To aid in sample retrieval, a plastic pipe extended out from each container to the edge of the pile. The samples were removed from the outdoor pile at approximately 50, 80 and $100 \mathrm{~d}$ after storage, except in the $2009 / 2010$ storage season where the last storage date was 20 January 2010 with only $77 \mathrm{~d}$ of storage (Table 3 ). The last retrieval date corresponded with the final day of sugar beet storage at the Dover Piling Station.
Grower income was calculated using the 2006, 2007, and 2008 MSC payment system (Wayne Martin, MSC, personal communication). In 2006, grower income in US dollars per fresh weight ton of sugar beets was $3.518 \times(\mathrm{S}-15.4)$, where $S$ is mean percent sucrose of the cooperative. In 2007 and 2008, grower income in US dollars per fresh weight ton of sugar beets was $G_{R w S} /$ $\mathrm{C}_{\mathrm{RWS}} \times \mathrm{SPS}$, where $\mathrm{G}_{\mathrm{RWS}}=\mathrm{RWS}$ for each individual grower, $\mathrm{C}_{\mathrm{RWS}}=$ mean RWS of the cooperative and SPS $=$ estimated selling price of sugar beets per fresh

Table 3. Sugar beet harvest date and length of storage in large outdoor piles at Dover, Ontario, Canada, during three storage seasons from 2007-2010

\begin{tabular}{lccc}
\hline Activity & $2007-2008$ & $2008-2009$ & $2009-2010$ \\
\hline Harvest & 01 Nov. & 28 Oct. & 4 Nov. \\
Retrieval no. and month & \multicolumn{3}{c}{ Days in storage } \\
1. Dec. & 49 & 48 & 40 \\
2. Jan. & 82 & 78 & 68 \\
3. Feb. & 104 & 100 & 77 \\
\hline
\end{tabular}


weight ton. In 2007 and 2008, the cooperative mean was 264.5 and 272 RWS per fresh weight ton of sugar beets, respectively, and the selling price was $\$ 35.00$ and $\$ 40.01$ per fresh weight ton of sugar beets, respectively. Thus, grower income per hectare was based not only on yield but also quality. All economic parameters and RWS were calculated on a fresh weight basis and data converted to metric units for analyses and presentation.

\section{Statistical Analysis}

The $\mathrm{N}$ fertilizer rate responses for sugar beet yield and quality parameters were fitted to linear and quadratic models using PROC REG model in SAS (SAS Institute, Inc. 2010). A paired t-test was used to compare the two pile management methods for $\mathrm{N}$ and cultivar trials separately. Each storage season of the cultivar trial was analyzed separately due to the significant change in the varieties tested and the number of entries from 2007 to 2009 in response to the industry's move to glyphosate-tolerant sugar beet varieties. All other data were subjected to analysis of variance using type I sums of squares in PROC MIXED model in SAS (SAS Institute, Inc. 2010), with year as a random effect and $\mathrm{N}$ application or cultivar and retrieval date as fixed effects. For all data sets, residual plots and the Shapiro-Wilk normality test were used to confirm analysis of variance assumptions. Data, where necessary, were subjected to a logarithmic transformation and results presented in the original scale. Data were pooled when there was no effect or interaction. Means separation was determined using Tukey-Kramer multiple comparison procedure. The type I error $(\alpha)$ was set at 0.05 .

\section{RESULTS AND DISCUSSION}

\section{Growing and Storage Season Conditions}

The 2006 growing season was cooler than the $30 \mathrm{yr}$ climatic mean with near typical precipitation April through August but 20 and $100 \%$ more rainfall than climatic norms in September and October, respectively (Table 2). Thus, sugar beet harvest was challenging. The excessive rainfall and poor field conditions resulted in an inability to harvest all treatments and an industry decision to forego the storage experiment for the 20062007 season. In the 2007 and 2009 growing seasons, drought conditions occurred with $25 \%$ less rainfall than the $30-\mathrm{yr}$ mean. Above average air temperatures in 2007 and dry soil conditions both years caused sugar beet drought stress, as indicated by lower yields and higher sucrose content. The 2008 growing season was ideal with near-average temperature and precipitation. Thus, diverse growing season conditions among years were observed. Sugar beets in all experimental sites were grown without irrigation as is typical for the region. Storage seasons for 2007-2008, 2008-2009 and 2009-2010 were ideal, with relatively constant temperatures and most precipitation as snow rather than rain.

\section{Nitrogen Fertilizer Effect on Sugar Beet Yield and Quality}

In the $\mathrm{N}$ trial, mean sugar beet yields were 93.6, 68.9, and $92.4 \mathrm{Mg} \mathrm{ha}^{-1}$ with $18.1,21.8$, and $19.5 \%$ sucrose content for 2006, 2007, and 2008, respectively (Fig. 1). Yields and sucrose contents were representative of the industry in the region and comparable with the 20062008 USDA reported yield of $55.8 \mathrm{Mg} \mathrm{ha}^{-1}$ (USDA 2010a).

In all $3 \mathrm{yr}, \mathrm{N}$ fertilizer was negatively related to $\%$ sucrose, RWS, and \% CJP, but positively related to the contaminant amino-N (Fig. 1). Thus, overall sugar beet quality declined with increased fertilizer $\mathrm{N}$ application. These results were expected, as a negative correlation between $\mathrm{N}$ fertilization and sucrose concentration/content has been well established (Eslami et al. 1988; Bilbao et al. 2004; Stevens et al. 2008). Clear juice purity was in agreement with previous research but sucrose content was higher than observed by Eslami et al. (1988). However, the observed high sucrose content in the $\mathrm{N}$ and cultivar trials was typical of sugar beets grown in southwestern Ontario (Michigan State University 2007 2009).

Based on MSC payments to growers, which were based on sugar beet root yield and quality, the most economical rate of $\mathrm{N}$ was approximately $112 \mathrm{~kg} \mathrm{~N} \mathrm{ha}^{-1}$ in 2006 and 2008 (Fig. 1). The most economical rate of $\mathrm{N}$ in 2007 was significantly higher at approximately $168 \mathrm{~kg} \mathrm{~N} \mathrm{ha}{ }^{-1}$ due to drought conditions, which lowered root yield, but increased sucrose content. Optimal $\mathrm{N}$ rates were in agreement with results reported from the Great Plains growing region (Lauer 1994; Eckhoff 1995) and Ontario grower practices as indicated by a 2009 survey of sugar beet producers (Van Eerd and Zandstra 2010). The observed yield response to drought conditions was comparable with Lauer (1994), who found lower sugar beet root yields with insufficient irrigation in Wyoming, USA. Because the drought conditions of 2007 can be considered atypical, research results suggest $112 \mathrm{~kg} \mathrm{~N} \mathrm{ha}^{-1}$ as the recommended rate of $\mathrm{N}$ fertilizer for sugar beets.

For all yield and quality parameters, the split $\mathrm{N}$ applications of $56+56$ and $84+84 \mathrm{~kg} \mathrm{~N}$ ha $^{-1}$ were not statistically different from the preplant $\mathrm{N}$ application of the same total $\mathrm{N}$ amount (112 and $168 \mathrm{~kg} \mathrm{~N}^{-1}$ ) (Fig. 1). Similarly, split N application has had no effect on impurities or yield in past research (Eckhoff 1995; Wiesler et al. 2002). The addition of $\mathrm{N}$ fertilizer midseason does not replace yield lost during earlier growth stages (Carter and Traveller 1981), which may explain why split $\mathrm{N}$ fertilizer application seemed ineffective in increasing root yield. Draycott and Christenson (2003) observed that during the $60 \mathrm{~d}$ period from sugar beet emergence to a leaf area index of $3, \mathrm{~N}$ was rapidly taken up to meet the needs of plant growth. In the present study, fertilizer application in the split $\mathrm{N}$ treatments occurred within $<60 \mathrm{~d}$ of each other, during the rapid growth period. The lack of differences between $\mathrm{N}$ 

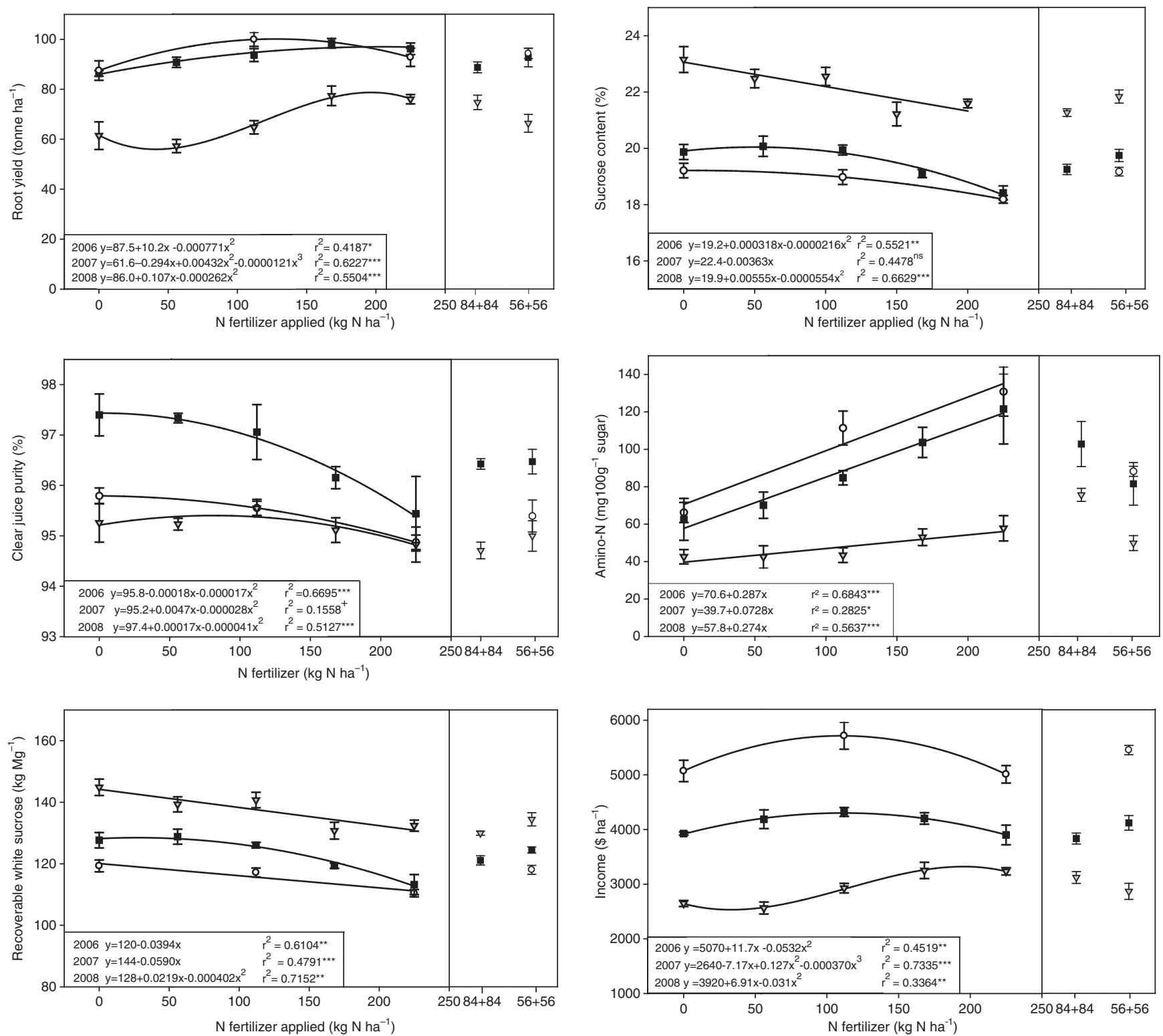

Fig. 1. At harvest in $2006(\bigcirc), 2007$ ( $\boldsymbol{\nabla}$ ), and 2008( $\mathbf{\square})$, sugar beet root yield and quality response to (calcium) ammonium nitrate fertilizer broadcast incorporated preplant or preplant and in-season before row closure at $56+56$ and $84+84$, respectively. Bars represent SE of means. $\mathrm{NS},{ }^{+}, *, * *, * * *$ Nonsignificant or significant at $P \leq 0.1,0.05,0.01$, or 0.001 , respectively $(n \geq 12)$.

preplant and split applications suggests there was adequate soil mineral $\mathrm{N}$ prior to the second $\mathrm{N}$ application.

\section{Nitrogen Fertilizer Effect on Sugar Beet Storage}

Nitrogen fertilizer rate was positively correlated to harvested sugar beet $\mathrm{N}$ concentration $(\%)$ in 2 of $3 \mathrm{yr}$ (2006 and 2008) and to $\mathrm{N}$ content $\left(\mathrm{kg} \mathrm{N}^{-1}\right)$ in all $3 \mathrm{yr}$ (Fig. 2). The drought conditions likely contributed to the lack of correlation between $\mathrm{N}$ rate and $\mathrm{N}$ concentration in 2007. Thus, there were differences in sugar beet $N$ content among treatments upon entering storage in large outdoor piles (Fig. 2).
As expected, sugar beet quality was higher at harvest and lower after storage in February (Table 4). For all parameters measured, there was no interaction between $\mathrm{N}$ rate and retrieval date, despite the fact that total $\mathrm{N}$ concentration and content in sugar beet roots were lower in the zero $\mathrm{N}$ control (Fig. 2). Although sugar beet quality tended to be lower with the split application of $\mathrm{N}$ compared with the same amount applied preplant, there were few significant differences. This result indicates that across the $\mathrm{N}$ rates and timings tested, $\mathrm{N}$ did not influence sugar beet storability over the $100 \mathrm{~d}$ period. In must be noted that conditions during all three storage 

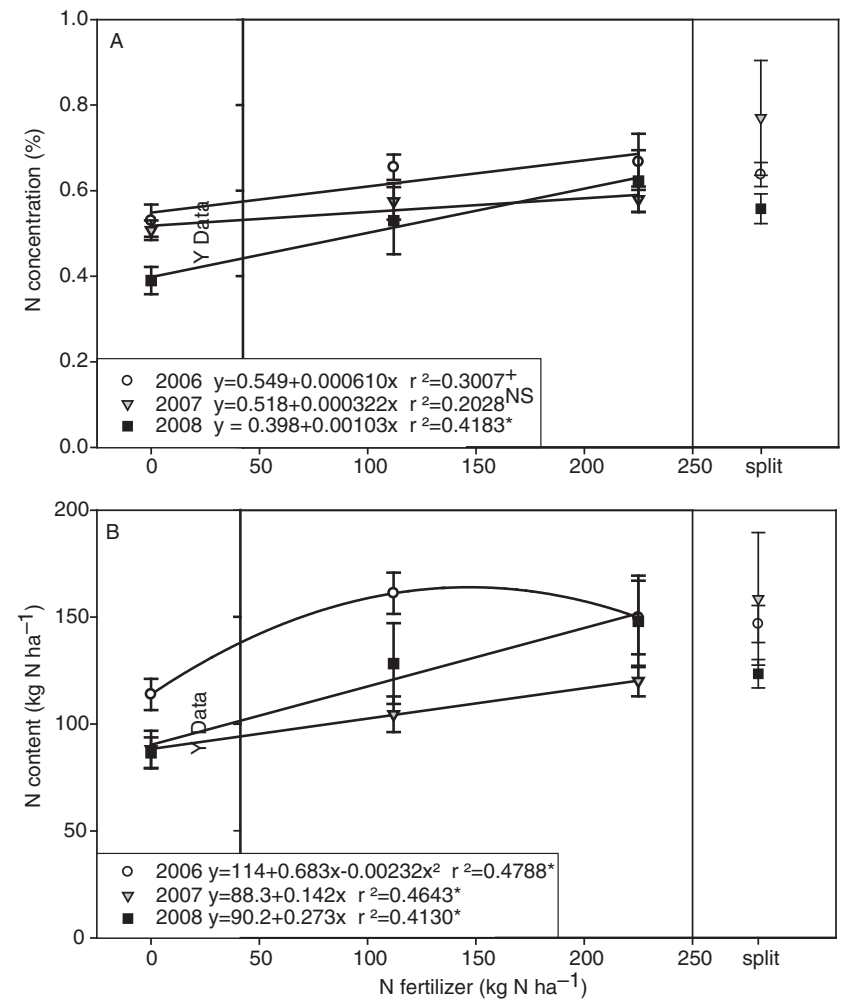

Fig. 2. At harvest in 2006 ( ○), 2007 ( $\boldsymbol{\nabla}$ ), and 2008( $\mathbf{\square})$, sugar beet root nitrogen $(\mathrm{N})$ accumulation expressed as percent nitrogen concentration (A) and on a dry weight basis (B) in response to preplant broadcast incorporated (calcium) ammonium nitrate fertilizer. The split treatment was two applications at $84+84 \mathrm{~kg} \mathrm{~N}^{-1}$ applied preplant and in-season before row closure, respectively. Bars representing SE of means. $\mathrm{NS},{ }^{+}, *$ Nonsignificant or significant at $P \leq 0.1$, or 0.05 , respectively $(n=12)$.

seasons were excellent (Table 2; Wayne Martin, MSC, personal communication), as no rot (data not shown) and very little weight loss were observed (Table 4). The effect of $\mathrm{N}$ fertility under less than ideal storage conditions is unknown.

\section{Cultivar Effect on Sugar Beet Storage}

In each storage season, differences in sucrose content were noted among cultivars, although significant differences in RWS were observed only in the first two seasons (Tables 5-7). There were no differences in percent weight loss or CJP during storage among varieties in any year (Tables 5-7). Overall sugar beet quality decreased over the storage period as evident by decreases in \% sucrose, \% CJP, and RWS (Tables 5-7). Similar to the $\mathrm{N}$ fertility storage trial (Table 4), in the 2007-2008 and 2008-2009 storage season, weight loss was significantly greater in January compared with December and February retrieval dates (Tables 5 and 6), likely due to lower temperatures and precipitation in January (Table 2). For all parameters, no cultivar by storage date interaction was found in any of the storage seasons (Tables 5-7), indicating that, in this study, cultivars did not differ in storability in large piles, which was consistent with the $\mathrm{N}$ fertility storage trial.

Sucrose losses over the storage period were expected (Kenter and Hoffmann 2009) and differences in storage characteristics among sugar beet cultivars were consistent with some (Martin et al. 2001b; Kenter and Hoffmann 2009), but not other studies (Campbell and Klotz 2007). Differences among sugar beet cultivars in concentrations of impurity factors, such as sodium, potassium, amino- $\mathrm{N}$ and betaine, were observed after $>100 \mathrm{~d}$ of pile storage (Martin et al. 2001b). Additionally, amino-N, dry matter, sucrose, invert sucrose and raffinose concentrations differed between two cultivars after pile storage (Kenter and Hoffmann 2009). It has therefore been suggested that genetic variability for storability may exist (Kenter and Hoffmann 2009) but cultivar screening under controlled storage conditions selects for good storage characteristics of commercially available cultivars, which ultimately may decrease the likelihood of observing a cultivar by retrieval date interaction in large outdoor piles.

Many sugar beet storage studies involve measurement of respiration in vitro (Cole 1977; Wyse et al. 1978; Wyse and Peterson 1979). Recent work has suggested that respiration is influenced more by environment and environment by genotype interactions than genotype alone (Campbell and Klotz 2007). Similarly, Kenter and Hoffmann (2009) observed that although sugar beet quality declined over $110 \mathrm{~d}$ of storage, there was a difference in sugar beet quality between varieties when the sugar beets were stored at $7^{\circ} \mathrm{C}$ compared with $20^{\circ} \mathrm{C}$. In our study, the outdoor storage conditions over the three storage seasons were ideal with minimal fluctuations in temperature (Table 2). The influence of cultivar on sugar beet storability may be more pronounced under unfavorable storage conditions (Martin et al. 2001b). Regardless, the lack of cultivar by storage date interaction for all storage quality parameters measured in all three storage seasons suggests that growers do not need to modify their cultivar selection to minimize storage losses.

\section{Pile Management Effect on Sugar Beet Storage}

In both trials in all three storage seasons, sucrose concentration (\%), RWS content, and grower income were significantly higher with the new length-removal technique compared with the standard end-removal method (Table 8). Likewise, percent CJP was numerically or significantly higher with the length-removal method compared with the end-removal method. In contrast, the length-removal method tended to increase the impurity amino-N (data not shown) compared with the standard end-removal method.

Overall, sugar beets from both $\mathrm{N}$ and cultivar trials had significantly better quality after up to $104 \mathrm{~d}$ of 
Table 4. Impact of $\mathrm{N}$ fertilizer and length of storage on sugar beet weight loss and quality during 2007-2008 and 2008-2009 storage seasons in large outdoor piles at Dover, Ontario, Canada ${ }^{\mathrm{z}}$

\begin{tabular}{|c|c|c|c|c|c|}
\hline N Applied ${ }^{\mathbf{y}}\left(\mathrm{kg} \mathrm{N} \mathrm{ha}^{-1}\right)$ & Weight $\operatorname{loss}^{\mathbf{x}}(\%)$ & Clear juice purity $(\%)$ & Sucrose $(\%)$ & Recoverable white sucrose $\left(\mathrm{kg} \mathrm{Mg}^{-1}\right)$ & Income $\left(\$ \mathrm{ha}^{-1}\right)$ \\
\hline 0 & 4.1 & $95.9 a$ & $20.5 a$ & $128 a$ & $3210 c$ \\
\hline 54 & 3.9 & $95.9 a$ & $20.5 a$ & $127 a$ & $3250 c$ \\
\hline 112 & 3.7 & $95.6 a b$ & $20.3 a b$ & $126 a b$ & $3370 a b c$ \\
\hline 168 & 4.2 & $95.0 b$ & $19.7 b c$ & $120 b c$ & $3610 a$ \\
\hline 225 & 3.6 & $95.3 a b$ & $19.7 b c$ & $121 b c$ & $3520 a b$ \\
\hline $84+84$ & 3.3 & $95.1 b$ & $19.2 c$ & $118 c$ & $3280 c b$ \\
\hline $56+56$ & 3.3 & $95.9 a$ & $20.1 a b$ & $125 a b$ & $3380 a b c$ \\
\hline \multicolumn{6}{|l|}{ Storage date } \\
\hline Harvest & - & $95.8 a$ & $20.7 a$ & $129 a$ & $3510 a$ \\
\hline Dec. & $3.3 b$ & $95.6 a$ & $19.6 c$ & $121 b$ & $3320 b c$ \\
\hline Jan. & $3.3 b$ & $96.0 a$ & $20.2 b$ & $126 a$ & $3450 a b$ \\
\hline Feb. & $4.6 a$ & $94.7 b$ & $19.5 c$ & $119 b$ & $3230 c$ \\
\hline \multicolumn{6}{|c|}{---------- $P$ value-------------- } \\
\hline Storage date & 0.017 & $<0.0001$ & $<0.0001$ & $<0.0001$ & $<0.0001$ \\
\hline $\mathrm{N} \times$ date & 0.8467 & 0.4319 & 0.9326 & 0.8002 & 0.9918 \\
\hline
\end{tabular}

${ }^{\mathrm{z}}$ Data were pooled means of two storage season with four replicates each. Within each column, means for $\mathrm{N}$ or date with a different letter indicate a statistical difference $(P \leq 0.05)$ based on Tukey-Kramer multiple range test.

$\mathbf{y}_{\text {(Calcium) Ammonium nitrate was broadcast incorporated preplant or preplant and in-season before row closure at } 84+84 \text { or } 56+56 \mathrm{~kg} N \text { ha }}{ }^{-1}$ respectively.

storage when piles were recovered by removing sugar beets along the length of the pile compared with the industry standard method of removing sugar beets from

Table 5. Impact of cultivar and storage duration on sugar beet weight loss and quality during 2007-2008 storage season in large outdoor piles at Dover, Ontario, Canada ${ }^{\mathrm{z}}$

\begin{tabular}{|c|c|c|c|c|}
\hline Cultivar & $\begin{array}{l}\text { Weight } \\
\operatorname{loss}^{\mathbf{y}}(\%)\end{array}$ & $\begin{array}{l}\text { Clear juice } \\
\text { purity }(\%)\end{array}$ & $\begin{array}{c}\text { Sucrose } \\
(\%)\end{array}$ & $\begin{array}{c}\text { Recoverable } \\
\text { white sucrose } \\
\left(\mathrm{kg} \mathrm{Mg}^{-1}\right)\end{array}$ \\
\hline $2771 \mathrm{RZ}$ & 2.5 & 94.9 & $19.7 a b$ & $121 b c$ \\
\hline 79 RZ & 1.8 & 94.9 & $19.4 b$ & $118 c$ \\
\hline $80 \mathrm{RZ}$ & 2.0 & 94.4 & $18.8 c$ & $113 d$ \\
\hline B-5411 R & 3.1 & 95.3 & $20.2 a$ & $124 a$ \\
\hline B-5451 & 2.3 & 94.7 & $19.7 a b$ & $120 b c$ \\
\hline B-5833 R & 3.2 & 95.1 & $19.3 b$ & $119 c$ \\
\hline B-5930 R & 2.6 & 94.9 & $20.1 a$ & $123 a b$ \\
\hline C-271 & 2.9 & 94.7 & $19.8 a b$ & $120 b c d$ \\
\hline C-355 & 2.3 & 95.0 & $19.6 b$ & $121 a b c$ \\
\hline C-963 & 2.5 & 94.9 & $19.8 a b$ & $121 a b c$ \\
\hline R-442 & 2.7 & 94.9 & $19.5 b$ & $119 b c$ \\
\hline R-509 & 2.8 & 95.1 & $19.8 a b$ & $121 a b c$ \\
\hline \multicolumn{5}{|l|}{ Storage date } \\
\hline Harvest & - & 94.9 & $19.9 a$ & $121 b c$ \\
\hline Dec. & $1.4 c$ & 95.1 & $19.9 a$ & $118 c$ \\
\hline Jan. & $4.1 a$ & 94.7 & $19.5 b$ & $113 d$ \\
\hline Feb. & $2.6 b$ & 94.7 & $19.4 b$ & $124 a$ \\
\hline \multicolumn{5}{|l|}{ Fixed Effects } \\
\hline Cultivar & 0.1219 & 0.3059 & 0.0001 & 0.0002 \\
\hline $\begin{array}{l}\text { Storage } \\
\text { date }\end{array}$ & $<0.0001$ & 0.1198 & 0.0011 & 0.0007 \\
\hline $\begin{array}{l}\text { Cultivar } \times \\
\text { date }\end{array}$ & 0.4035 & 0.0658 & 0.4948 & 0.5599 \\
\hline
\end{tabular}

${ }^{\mathrm{z}}$ Data were means of three replicates. Within each column, means for variety or date with a different letter indicate a statistical difference $(P \leq 0.05)$ based on Tukey-Kramer multiple range test.

${ }^{y}$ Weight loss was relative to beet weight at harvest. the face-end of the pile. Although conditions during all three storage seasons were ideal, one would expect this trend to hold true under more challenging storage conditions. Past research on sugar loss in large uncovered piles has found that $40 \%$ of the recoverable sugar loss occurred in the outer $60 \mathrm{~cm}$ of the pile, despite the outer rim representing only $17 \%$ of pile volume (Akeson et al. 1974). Thus, one would expect increased sucrose recovery with the new length-recovery method,

\begin{tabular}{|c|c|c|c|c|}
\hline Cultivar & $\begin{array}{l}\text { Weight } \\
\operatorname{loss}^{\mathbf{y}}(\%)\end{array}$ & $\begin{array}{l}\text { Clear juice } \\
\text { purity }(\%)\end{array}$ & $\begin{array}{c}\text { Sucrose } \\
(\%)\end{array}$ & $\begin{array}{l}\text { Recoverable white } \\
\text { sucrose }\left(\mathrm{kg} \mathrm{Mg}^{-1}\right)\end{array}$ \\
\hline C-RR827 & 3.2 & 96.0 & $20.0 a$ & $125 a$ \\
\hline HM-27RR & 3.4 & 96.1 & $19.6 b$ & $123 b$ \\
\hline HM-28RR & 3.3 & 96.1 & $19.6 b$ & $123 b$ \\
\hline HM-29RR & 3.7 & 96.2 & $19.8 b$ & $124 a b$ \\
\hline \multicolumn{5}{|l|}{ Storage date } \\
\hline Harvest & - & $96.6 a$ & 19.8 & $125 a$ \\
\hline Dec. & $2.2 c$ & $96.0 b$ & 19.8 & $123 a b$ \\
\hline Jan. & $4.5 a$ & $95.7 b$ & 19.6 & $122 b$ \\
\hline Feb. & $3.6 b$ & $96.1 b$ & 19.8 & $124 a$ \\
\hline \multicolumn{5}{|l|}{$\begin{array}{l}\text { Fixed } \\
\text { Effects }\end{array}$} \\
\hline \multicolumn{5}{|l|}{ Effects } \\
\hline Cultivar & 0.6496 & 0.9752 & 0.0001 & 0.0232 \\
\hline $\begin{array}{l}\text { Storage } \\
\text { date }\end{array}$ & 0.0001 & 0.0002 & 0.3989 & 0.0138 \\
\hline $\begin{array}{l}\text { Cultivar } \times \\
\text { date }\end{array}$ & 0.6736 & 0.0699 & 0.6501 & 0.4780 \\
\hline
\end{tabular}

${ }^{\mathrm{z}}$ Data were means of four replicates. Within each column, means for cultivar or date with a different letter indicate a statistical difference $(P \leq 0.05)$ based on Tukey-Kramer multiple range test.

${ }^{\mathrm{y}}$ Weight loss was relative to beet weight at harvest. 
Table 7. Impact of cultivar and storage duration on sugar beet weight loss and quality during 2009-2010 storage season in large outdoor piles at Dover, Ontario, Canada

\begin{tabular}{|c|c|c|c|c|}
\hline Cultivar & $\begin{array}{c}\text { Weight } \\
\operatorname{loss}^{\mathrm{y}}(\%)\end{array}$ & $\begin{array}{l}\text { Clear juice } \\
\text { purity }(\%)\end{array}$ & $\begin{array}{c}\text { Sucrose } \\
(\%)\end{array}$ & $\begin{array}{c}\text { Recoverable } \\
\text { white sucrose } \\
\left(\mathrm{kg} \mathrm{Mg}^{-1}\right)\end{array}$ \\
\hline B-17RR32 & 1.7 & 94.6 & $19.5 b$ & 115 \\
\hline B-17RR62 & 1.7 & 94.0 & $19.8 a b$ & 118 \\
\hline C-RR824 & 1.5 & 95.5 & $19.5 b$ & 121 \\
\hline C-RR827 & 1.9 & 94.8 & $19.8 a b$ & 120 \\
\hline C-RR $827^{x}$ & 1.8 & 94.8 & $20.1 a$ & 123 \\
\hline HM-27RR & 1.6 & 94.8 & $20.1 a$ & 123 \\
\hline HM-28RR & 1.6 & 94.3 & $19.5 b$ & 114 \\
\hline HM-29RR & 1.8 & 95.1 & $19.6 a b$ & 120 \\
\hline HM-42RR & 1.4 & 95.0 & $20.0 a$ & 123 \\
\hline HM-50RR & 1.4 & 94.5 & $20.1 a$ & 122 \\
\hline HM-50RR ${ }^{x}$ & 1.2 & 94.6 & $19.7 a b$ & 119 \\
\hline SX-1260RR & 2.1 & 94.3 & $19.8 a b$ & 119 \\
\hline \multicolumn{5}{|l|}{ Storage date } \\
\hline Harvest & - & $95.5 a$ & $19.9 a$ & $123 a$ \\
\hline Dec. & $1.6 b$ & $94.3 c$ & $19.6 b$ & $118 b c$ \\
\hline Jan. & $1.1 c$ & $94.4 c$ & $20.0 a$ & $121 a b$ \\
\hline Feb. & $2.2 a$ & $94.5 b$ & $19.6 b$ & $116 c$ \\
\hline \multicolumn{5}{|l|}{$\begin{array}{l}\text { Fixed } \\
\text { Effects }\end{array}$} \\
\hline Effects & & & & \\
\hline Cultivar & 0.5584 & 0.2386 & 0.0278 & 0.0546 \\
\hline $\begin{array}{l}\text { Storage } \\
\text { date }\end{array}$ & 0.0001 & 0.0001 & 0.0049 & 0.0009 \\
\hline $\begin{array}{l}\text { Cultivar } \times \\
\text { date }\end{array}$ & 0.3087 & 0.7303 & 0.1989 & 0.5023 \\
\hline
\end{tabular}

${ }^{\mathbf{z}}$ Data were means of three replicates. Within each column, means for cultivar or date with a different letter indicate a statistical difference $(P \leq 0.05)$ based on Tukey-Kramer multiple range test.

${ }^{\mathbf{y}}$ Weight loss was relative to beet weight at harvest.

${ }^{\mathrm{x}}$ Denotes cultivars that received a single application of azoxystrobin (Quadris ${ }^{\circledR}$ ) at the 6-8 leaf stage.

because it removes a larger area of the outer rim of the pile on both sides compared with the end-removal method.

When sugar beets were removed along the length of the pile, a rind of degraded sugar beets does not form along the $300 \mathrm{~m}$ length of pile. Preventing the formation of a rind is speculated to improve pile ventilation and overall sugar beet quality during storage. This may be beneficial for two reasons. First, fewer degraded sugar beets are shipped to the factory for processing with the new length-removal method, whereas the standard end-removal method includes degraded sugar beets thereby lowering processing efficiency. Second, air flow and temperature control are important in maintaining sugar beet sucrose levels in storage piles (Bugbee 1993); thus removing the rind may provide better ventilation and improve storage conditions. Considering that the sugar beet samples were placed in the middle of the pile and not within the rind, the length-removal method clearly resulted in higher quality beets (Table 8 ) likely due to better storage conditions, which may be attributed to better ventilation than the end-removal method.

Higher quality sugar beets from the length-removal method may also be due to greater sugar beet weight loss when compared with sugar beets managed using the end-removal method (Table 8). The greater weight loss was likely due to greater ventilation of low humidity air in the length-removal pile. Lighter sugar beets, due to moisture loss, will reduce the cost of shipping sugar beets from the piling yard to the processing plant and may lower sucrose production costs by lowering the amount of water that needs to be removed during processing.

Other possible efficiencies with the length-removal method of pile management may result from the use of a EuroMaus ${ }^{\circledR}$. The EuroMaus ${ }^{\circledR}$ is a self-propelled machine, which lifts, cleans, and elevates sugar beets into trailers for shipment to the processing plant. It was developed in Europe to load sugar beets from shortterm storage piles (clamps) in grower's fields. Effective cleaning of the sugar beets results in less dirt being shipped, which saves on shipping costs and reduces the amount of beet cleaning needed at the factory before sucrose extraction.

Although the results show that growers do not have to modify their $\mathrm{N}$ management practices or select specific varieties to maintain storage quality, they indicate that the length-removal method of pile management improves storability compared with the standard

Table 8. Impact of sugar beet removal method on sugar beet weight loss and quality after 77 to $104 \mathrm{~d}$ of storage in large outdoor piles at Dover, Ontario, Canada, during three storage seasons from 2007-2010

\begin{tabular}{|c|c|c|c|c|c|c|}
\hline Trial & Removal method & Weight $\operatorname{loss}^{\mathbf{y}}(\%)$ & Sucrose $(\%)$ & Clear juice purity $(\%)$ & Recoverable white sucrose $\left(\mathrm{kg} \mathrm{Mg}^{-1}\right)$ & Income $\left(\$ \mathrm{ha}^{-1}\right)$ \\
\hline \multirow[t]{3}{*}{ Nitrogen } & End & 2.7 & 19.3 & 94.5 & 121 & 2080 \\
\hline & Length & 3.9 & 19.7 & 94.7 & 123 & 3190 \\
\hline & $P$ value & $<0.0001$ & 0.0067 & 0.0926 & 0.0113 & $<0.0001$ \\
\hline \multirow[t]{2}{*}{ Cultivar } & $\begin{array}{l}\text { End } \\
\text { Length }\end{array}$ & $\begin{array}{l}2.4 \\
3.0\end{array}$ & $\begin{array}{l}19.2 \\
19.6\end{array}$ & $\begin{array}{l}92.8 \\
94.8\end{array}$ & $\begin{array}{l}116 \\
123\end{array}$ & \\
\hline & $P$ value & 0.0054 & 0.0016 & $<0.0001$ & 0.0002 & \\
\hline
\end{tabular}

${ }^{\mathbf{z}}$ Data were means of two or three storage season with four or three replicates each for the nitrogen and cultivar trial, respectively. Statistical significance $(P \leq 0.05)$ was based on a one-tail paired t-test.

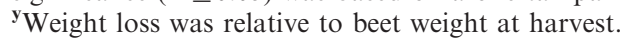


end-removal method. Based on an estimated 2.8 million $\mathrm{Mg}$ of sugar beets stored by MSC and the mean difference of $5 \mathrm{~kg}$ of recoverable white sucrose $\mathrm{Mg}^{-1}$ between the two pile management methods, switching to the length-removal method would increase white sucrose recovery by $14000 \mathrm{Mg}$. Not all sugar beets are stored for the full season; therefore, effects would be expected to be less for shorter storage durations. Based on the 20072010 average sucrose selling price of $\$ 0.42 \mathrm{~kg}^{-1}$ (USDA $2010 \mathrm{~b}$ ), if one considers a conservative $7000 \mathrm{Mg}$ increase in white sucrose by switching to the lengthremoval method, this would amount to an increase in estimated revenue of $\$ 2.9$ million and $\$ 10$ million for the MSC cooperative and the sugar beet industry in Alberta, respectively. Thus, implementing the lengthremoval method of pile management has the potential to improve overall sugar beet processing efficiency and profitability.

\section{ACKNOWLEDGEMENTS}

Funding for this project was provided in part by Agriculture and Agri-Food Canada through the Agricultural Adaptation Council and the Alberta Agriculture and Food Program. Other sources of funding include the Ontario Sugarbeet Growers Association, and Ontario Ministry of Agriculture, Food and Rural Affairs. Inkind analyses were provided by A\&L Laboratories Canada Inc. and Michigan Sugar Company Inc. and weather data from Weather Innovations Incorporated (WIN). The authors are especially grateful to Brian Fox, Wayne Martin, Mike Zink, Rob Squire, Anne Verhallen, and Janice LeBoeuf.

Akeson, W. R. and Widner, J. N. 1981. Differences among sugarbeet cultivars in sucrose loss during storage. J. Am. Soc. Sugar Beet Technol. 21: 80-91.

Akeson, W. R., Stout, E. L. and Fox, S. D. 1974. Effect of pile covering on weight and sugar shrink in pile rims. J. Am. Soc. Sugar Beet Technol. 18: 108-115.

Bilbao, M., Martinez, J. J. and Delgado, A. 2004. Evaluation of soil nitrate as a predictor of nitrogen requirement for sugar beet grown in Mediterranean climate. Agron. J. 96: $18-25$.

Bugbee, W. M. 1993. Storage. Chapter 14, Pages 551-570 in D. A. Cooke and R. K. Scott, eds. The sugar beet crop: Science into practice. Chapman and Hall, London, UK.

Campbell, L. G. and Klotz, K. L. 2007. Characterizing sugarbeet varieties for postharvest storage losses is complicated by environmental effects and genotype $\times$ environment interactions. Can. J. Plant Sci. 87: 121-127.

Carruthers, A. and Oldfield, J. F. T. 1961. Methods for the assessment of beet quality. Int. Sugar J. 63: 72-74.

Carter, J. N. and Traveller, D. J. 1981. Effect of time and amount of nitrogen uptake on sugarbeet growth and yield. Agron. J. 73: 665-671.

Chaudhary, G. N. 2009. The economics of sugar beet production in Alberta. Government of Alberta. Edmonton, AB. AGDEV 171/821-5 p. 39.
Cole, D. F. 1977. Effect of cultivar and mechanical damage on respiration and storability of sugarbeet roots. J. Am. Soc. Sugar Beet Technol. 19: 240-245.

Cole, D. F. and Bugbee, W. M. 1976. Changes in resident bacteria, $\mathrm{pH}$, sucrose, and invert sugar levels in sugarbeet roots during storage. Appl. Environ. Microbiol. 31: 754-757.

Draycott, A. P. and Christenson, D. R. 2003. Nitrogen. Pages 7-33 in Nutrients for sugar beet production. Soil-plant relationships. CABI Publishing, Wallingford, UK.

Eckhoff, J. L. A. 1995. Split application of nitrogen on irrigated sugarbeet. J. Sugar Beet Res. 32: 175-183.

Eslami, S. M., Lee, G. S. and Schmehl, W. R. 1988. Nutrient concentrations in sugarbeet senescing leaves during the season and in six plant parts at harvest. J. Sugar Beet Res. 25: 11-27. Halvorson, A., Hartman, G. P., Cole, D. F., Haby, V. A. and Baldridge, D. E. 1978. Effect of $\mathrm{N}$ fertilization on sugarbeet crown tissue production and processing quality. Agron. J. 70: 876-880.

Kenter, C. and Hoffmann, C. M. 2009. Changes in the processing quality of sugar beet (Beta vulgaris L.) during long-term storage under controlled conditions. Int. J. Food Sci. Technol. 44: 910-917.

Last, P. J., Draycott, A. P. and Hull, R. 1976. The influence of level of topping and other cultural practices on sugar beet yield and quality. Int. Sugar J. 78: 167-170.

Lauer, J. G. 1994. Early harvest of sugarbeet: yield and quality response to irrigation, cultivar and nitrogen. J. Sugar Beet Res. 21: 117-133.

Martin, S. S., Narum, J. A. and Chambers, K. H. 2001 a. Sugarbeet biochemical quality changes during pile storage. Part I. Sugars. J. Sugar Beet Res. 38: 35-53.

Martin, S. S., Narum, J. A. and Chambers, K. H. 2001 b. Sugarbeet biochemical quality changes during factory pile storage. Part II. Non-sugars. J. Sugar Beet Res. 38: 173-188.

Michigan State University. 2007-2009. Sugarbeet advancement research book. Saginaw Valley Research and Extension Center - Michigan Sugarbeet Information. [Online] Available: http://www.michigansugar.com/agriculture/advancement_ archive.php [2011 Jun. 27].

Rutherford, P. M., McGill, W. B., Arocena, J. M. and Figueiredo, C. T. 2008. Total nitrogen. Pages 239-250 in M. R. Carter and E. G. Gregorich, eds. Soil sampling and methods of analysis. 2nd ed. CRC Press Inc., Boca Ratan, FL. SAS Institute, Inc. 2010. Release 9.1. SAS Institute, Inc., Cary, NC.

Scott, R. K. and Jaggard, K. W. 2000. Impact of weather, agronomy and breeding on yields of sugarbeet grown in UK since 1970. J. Agric. Sci. (Camb.) 131: 341-352.

Stevens, W. B., Violett, R. D., Skalsky, S. A. and Mesbah A. O. 2008. Response of eight sugarbeet varieties to increasing nitrogen application: I. Root, sucrose, and top yield. J. Sugar Beet Res. 45: 65-83.

USDA. 2010a. National statistics for sugarbeets. National Agricultural Statistics Service. [Online] Available: http:// www.nass.usda.gov/ [2011 Jun. 27].

USDA. 2010b. Sugars and sweeteners. Economic Research Service. [Online] Available: http://www.ers.usda.gov/ [2011 Jun. 27].

Van Eerd, L. L. and Zandstra, J. W. 2010. ADV-0253 Enancing sugarbeet storage quality. Final Report to Agricultural Adaptation Council's CanAdvance Program. May 2010. pp 22. [Online] Available: http://www.ridgetownc.uoguelph. 
$\mathrm{ca} /$ research/research_reports_profile.cfm?profile=vaneerd\& name $=$ Dr. $\% 20$ Laura $\% 20$ Van\%20Eerd [2011 Jun. 27].

Wiesler, F., Bauer, M., Kamh, M., Engels, T. and Reusch, S. 2002. The crop as indicator for sidedress nitrogen demand in sugar beet production-limitations and perspectives. J. Plant Nutr. Soil Sci. 165: 93-99.
Wyse, R. E. and Peterson, C. L. 1979. Effect of injury on respiration rates of sugarbeet roots. J. Am. Soc. Sugar Beet Technol. 18: 269-280.

Wyse, R. E., Therurer, J. C. and Doney, D. L. 1978. Genetic variability in post-harvest respiration rates of sugarbeet roots. Crop Sci. 18: 264-266. 